Check for updates

Cite this: RSC Adv., 2017, 7, 53631

Received 28th September 2017 Accepted 16th November 2017

DOI: 10.1039/c7ra10721h

rsc.li/rsc-advances

\section{Investigation of $\mathrm{SO}_{2}$ tolerance of $\mathrm{Ce}$-modified activated semi-coke based catalysts for the $\mathrm{NO}+$ $\mathrm{CO}$ reaction $\dagger$}

\author{
Zhiqiang Wang, ${ }^{a}$ Luyuan Wang, ${ }^{\text {*a }}$ Xingxing Cheng, (D) *a Chunyuan $\mathrm{Ma}^{\mathrm{a}}$ \\ and Yukun Qin ${ }^{\mathrm{ab}}$
}

\begin{abstract}
Activated semi-coke was loaded with Fe-Co mixed oxides and doped with an optimized amount of cerium oxides. This prepared catalyst exhibited excellent $\mathrm{NO}$ removal (deNO) activity, and also showed outstanding $\mathrm{SO}_{2}$ resistance at $250^{\circ} \mathrm{C}$. To understand the $\mathrm{SO}_{2}$ tolerance mechanism, the catalysts were characterized by scanning electron microscopy, energy-dispersive $\mathrm{X}$-ray spectroscopy, $\mathrm{X}$-ray diffraction, in situ Fouriertransform infrared spectroscopy, $\mathrm{H}_{2}$-temperature-programmed reduction, and $\mathrm{SO}_{2}$-temperatureprogrammed desorption, as well as $\mathrm{CO}-$ deNO activity testing under different conditions. The results indicate that the $\mathrm{Ce}$ (molar ratio $=0.1$ ) doped onto the $\mathrm{Fe}-\mathrm{Co}$ binary oxide catalysts would promote the generation of $\mathrm{Ce}_{2}\left(\mathrm{SO}_{4}\right)_{3}$. This generation could prevent the active metal oxides from being poisoned by $\mathrm{SO}_{2}$. Furthermore, this kind of sulfate would weaken the interaction between $\mathrm{SO}_{2}$ and $\mathrm{NO}$, so that the adsorbed NO will have a better opportunity to react with $\mathrm{CO}$.
\end{abstract}

\section{Introduction}

Selective catalytic reduction of $\mathrm{NO}_{x}$ with $\mathrm{NH}_{3}\left(\mathrm{NH}_{3}\right.$-SCR $)$ has proven to be the most effective process for removing $\mathrm{NO}_{x}$ from stationary sources and diesel engines. ${ }^{1-3}$ Moreover, it is presently the most applied method for $\mathrm{NO}_{x}$ removal in power plants. ${ }^{1,4}$ However, the $\mathrm{NH}_{3}$-SCR process has some disadvantages, such as $\mathrm{NH}_{3}$ leaks, the toxicity of vanadium catalysts, and use of air preheater blocks. ${ }^{5,6}$ Recently, researchers have proposed that the leaked $\mathrm{NH}_{3}$ will interact with $\mathrm{SO}_{2}$ to form $\left(\mathrm{NH}_{4}\right)_{2} \mathrm{SO}_{4}$. This sulfate evolves in the natural atmosphere; furthermore, it is a major contributor to the formation of Chinese haze. ${ }^{7}$ Therefore, it is extremely urgent to provide a substitute for the $\mathrm{NH}_{3}$-SCR process.

Among the processes for $\mathrm{NO}_{x}$ removal from vehicle exhaust, selective catalytic reduction with hydrocarbon (HC-SCR ${ }^{6}$ and three-way catalyst technology (TWC) ${ }^{8}$ have been widely investigated. These technologies make almost no contribution to the $\mathrm{NH}_{3}$ leaks. If these could be applied to the $\mathrm{NO}_{x}$ elimination process in power plants, the Chinese haze could be alleviated. In recent years, researchers have begun to focus on investigations such as these. ${ }^{9-12}$ However, the application of the new

${ }^{a}$ National Engineering Lab for Coal-fired Pollutants Emission Reduction, Shandong Provincial Key Lab of Energy Carbon Reduction and Resource Utilization, Shandong University, Jinan, China 250061. E-mail: xcheng@sdu.edu.cn; luyuanwang1988@ gmail.com

${ }^{b}$ School of Power Engineering, Harbin Institute of Technology, Harbin, China 150001 $\dagger$ Electronic supplementary information (ESI) available. See DOI: 10.1039/c7ra10721h processes has faced some difficulties: one is that the presence of $\mathrm{O}_{2}$ will consume the majority of the reductant. ${ }^{10-12}$ Therefore, in consideration of the negative effects of $\mathrm{O}_{2}$, the $\mathrm{NO}_{x}$ adsorptionreduction process (model reactor in Fig. S1 $\dagger$ ) was proposed by Professor $\mathrm{Bi}^{1{ }^{10-12}}$ This technology could also achieve high deNO $\mathrm{N}_{x}$ efficiency. Developed from the TWC process, $\mathrm{CO}-\mathrm{deNO}_{x}$ is very suitable for $\mathrm{NO}_{x}$ adsorption-reduction. This is because $\mathrm{CO}$ is inexpensive, can easily be produced, and cannot generate solid carbon deposits ${ }^{10,13}$ upon reaction with NO. It is widely reported that transition metal oxides could catalyze the $\mathrm{NO}+\mathrm{CO}$ reaction efficiently. In fact, $\mathrm{Cu}-{ }^{14-19} \mathrm{Co}^{-20-22} \mathrm{Fe}^{-13}{ }^{13} \mathrm{Ni}-{ }^{23}$ and $\mathrm{Mn}$-based ${ }^{14,24}$ oxides, as either loaded or non-loaded catalysts, exhibit excellent CO-deNO efficiency at temperatures between 150 and $300^{\circ} \mathrm{C}$. Furthermore, $\mathrm{CeO}_{2}, \mathrm{SnO}_{2}$, or $\mathrm{ZrO}_{2}$ mixed with transition metals and carbon supported metal catalysts also promote the efficient reaction of $\mathrm{CO}$ with NO. ${ }^{17,25-27}$ As for the mechanism of the $\mathrm{NO}+\mathrm{CO}$ reaction, it is established that at relatively low temperatures, NO coordinates with the metal cation and generates nitrites. ${ }^{5,13,28}$ Subsequently, the formed nitrites can react with $\mathrm{CO}$ to yield $\mathrm{N}_{2} \mathrm{O}$ and $\mathrm{CO}_{2}{ }^{5,28}$ However, as the temperature increases, the coordinated $\mathrm{NO}$ is transformed to nitrates that react with $\mathrm{CO}$, generating $\mathrm{N}_{2}$ and $\mathrm{CO}_{2}{ }^{5,13,27,28}$ In our previous study, CO-deNO (catalyzed by semi-coke based catalysts) were applied to a $\mathrm{NO}_{x}$ adsorption-reduction process, and the deNO efficiency was relatively high., ${ }^{5,927}$ However, in this process, $\mathrm{SO}_{2}$ can be adsorbed onto the adsorbents more easily than NO. ${ }^{5}$ Even if the deNO reactors are placed downstream of the desulfurization equipment, there is an appreciable quantity of $\mathrm{SO}_{2}$ in the flue gas, which can severely decrease the deNO activity. As shown in our previous studies, ${ }^{5,28}$ the addition of $\mathrm{SO}_{2}$ 
reduces NO conversion by approximately $60 \%$ at $250{ }^{\circ} \mathrm{C}$, and the coordinated $\mathrm{SO}_{2}$ induced the reversible catalyst deactivation. Therefore, the improvement of $\mathrm{SO}_{2}$ resistance for semi-coke based catalysts should be investigated.

As for the deactivation of catalysts caused by $\mathrm{SO}_{2}$, the most accepted theses are as follows: (1) the competitive adsorption between $\mathrm{NO}$ and $\mathrm{SO}_{2}$ can result in no active sites being available for $\mathrm{NO}$ on the catalyst surface; ${ }^{29}$ (2) $\mathrm{SO}_{2}$ can easily occupy the acid site that is the vital point for $\mathrm{NH}_{3}-\mathrm{SCR} ;{ }^{\mathbf{1 , 3 0}}$ (3) the interaction of $\mathrm{SO}_{2}$ and $\mathrm{H}_{2} \mathrm{O}$ can generate some surface sulfates; for instance, $\mathrm{Mn},{ }^{30} \mathrm{Cu},{ }^{31} \mathrm{Co}^{32}$ oxides are very actively drawn to $\mathrm{SO}_{2}$; therefore, the $\mathrm{SO}_{2}$ present will easily transform these oxides to sulfates; and (4) the formation of $\left(\mathrm{NH}_{4}\right)_{2} \mathrm{SO}_{4}$ or $\mathrm{NH}_{4} \mathrm{HSO}_{4}\left(\mathrm{NH}_{3}\right.$ SCR) will accumulate on the surface, which would reduce the available surface area and then deactivate the catalysts. ${ }^{33,34}$ Therefore, to understand the $\mathrm{SO}_{2}$ poisoning mechanism, researchers have focused on the investigation on the $\mathrm{SO}_{2}$ tolerance of $\mathrm{deNO}_{x}$ catalysts. Until now, breakthroughs in the investigation of $\mathrm{SO}_{2}$ resistance have occurred in two domains, viz. the doping of $\mathrm{SO}_{2}$ resistant metals onto active metals and the optimization of the micro-structure. From wide study, it is known that the doping of $\mathrm{Ti}^{-},{ }^{32,35} \mathrm{Zr}-{ }^{36} \mathrm{Sn}-{ }^{37} \mathrm{Ce}-,{ }^{2,33}$ oxides onto the SCR catalysts as active components or supporters can reduce the thermal stability of the surface sulfates. The excellent decomposing performance of surface sulfates is the vital factor for $\mathrm{SO}_{2}$ resistance. ${ }^{2}$ Recently, it was established that $\mathrm{SO}_{2}$ could directionally accumulate on the surface of $\mathrm{CeO}_{2}$ affording some bulk-like sulfates, ${ }^{\mathbf{1 , 2}}$ which would be beneficial for NO reacting with the active metals. As for the micro-structure optimization, researchers invented mipor supporters like SSZ$13 .^{38-40}$ The pore size of these supports is smaller than the molecular vibration radius of $\mathrm{SO}_{2}$, but larger than that of $\mathrm{NO}_{x}$, which can prevent the generation of surface sulfates.

In the present study, based on the previous investigation on the $\mathrm{SO}_{2}$ tolerance of activated semi-coke based catalysts, ${ }^{5}$ we coimpregnated $\mathrm{Ce}$ and $\mathrm{Fe}-\mathrm{Co}$ binary oxides onto the coke based supports using a hydrothermal method. The CO-deNO results demonstrate that $\mathrm{Ce}$ doping can increase the $\mathrm{SO}_{2}$-resistant performance. A variety of methods were used to obtain insight into the mechanism, including scanning electron microscopy (SEM), X-ray diffraction (XRD), X-ray photoelectron spectroscopy (XPS), $\mathrm{N}_{2}$ physisorption, temperature-programmed reduction of hydrogen $\left(\mathrm{H}_{2}-\mathrm{TPR}\right)$, and temperature-programmed desorption of $\mathrm{SO}_{2}$ ( $\mathrm{SO}_{2}$-TPD). The evolution of surface components was also detected by in situ diffuse reflectance infrared Fourier transform spectroscopy (DRIFTS).

\section{Experiments}

\subsection{Catalysts preparation}

Commercial semi-coke (Shaanxi Shenmu Coal Mine Co., Ltd., China) was first ground and sieved into granules with diameters of 1.02-1.27 mm (labeled SC). Second, the SC particles were activated using nitric acid $(30 \mathrm{wt} \%)$ at $80{ }^{\circ} \mathrm{C}$ for $2 \mathrm{~h}$. Next, after the particles had been washed with deionized water, they were dried at $120{ }^{\circ} \mathrm{C}$ for $6 \mathrm{~h}$, followed by calcination in $\mathrm{Ar}$ at $700{ }^{\circ} \mathrm{C}$ for $4 \mathrm{~h}$ (labeled ASC).
Table 1 The parameters of the prepared catalysts

\begin{tabular}{llll}
\hline Catalysts & $\begin{array}{l}\text { Concentration } \\
\text { of } \mathrm{Fe}\left(\mathrm{NO}_{3}\right)_{3} \\
\left.(\mathrm{~mol} \mathrm{~L})^{-1}\right)\end{array}$ & $\begin{array}{l}\text { Concentration } \\
\text { of } \mathrm{Co}\left(\mathrm{NO}_{3}\right)_{3} \\
(\mathrm{~mol} \mathrm{~L}\end{array}$ & $\begin{array}{l}\text { Concentration } \\
\text { of } \mathrm{Ce}\left(\mathrm{NO}_{3}\right)_{3} \\
\left(\mathrm{~mol} \mathrm{~L}^{-1}\right)\end{array}$ \\
\hline $\mathrm{Fe}_{0.8} \mathrm{Co}_{0.2} / \mathrm{ASC}$ & 1.653 & 0.413 & \\
$\mathrm{Fe}_{0.8} \mathrm{Co}_{0.2} \mathrm{Ce}_{0.05} / \mathrm{ASC}$ & 1.653 & 0.413 & 0.103 \\
$\mathrm{Fe}_{0.8} \mathrm{Co}_{0.2} \mathrm{Ce}_{0.1} / \mathrm{ASC}$ & 1.653 & 0.413 & 0.207 \\
$\mathrm{Fe}_{0.8} \mathrm{Co}_{0.2} \mathrm{Ce}_{0.2} / \mathrm{ASC}$ & 1.653 & 0.413 & 0.413
\end{tabular}

The supports (ASC) were loaded with transition metals using a hydrothermal method: ferric nitrate, cobalt nitrate, and cerium nitrate (analytical-reagent grade, Sinopharm Chemical Reagent Co., Ltd.) were first dissolved in deionized water for use as precursors. Table 1 summarizes the loading-amount parameters of the prepared catalysts. Then, ASC $\left(\begin{array}{ll}5 & \mathrm{~g}\end{array}\right)$ immersed in $30 \mathrm{~mL}$ of the precursor was transferred to a stainless-steel autoclave. The autoclave was maintained at $160{ }^{\circ} \mathrm{C}$ for $24 \mathrm{~h}$. Next, the activated coke particles were washed using deionized water and then dried at $120{ }^{\circ} \mathrm{C}$ for $6 \mathrm{~h}$, followed by calcination in $\mathrm{Ar}$ at $700{ }^{\circ} \mathrm{C}$ for $4 \mathrm{~h}$.

\subsection{Characterization}

The textural properties were evaluated by physical adsorption of $\mathrm{N}_{2}$ at $77 \mathrm{~K}$ using an automatic surface analyzer (Quantachrome Autosorb 1C), and the specific surface areas and pore volumes were calculated using density functional theory (DFT) from the $\mathrm{N}_{2}$ ad-/de-sorption isotherms. XRD detection was performed on a Rigaku D/max 2400 diffractometer using $\mathrm{Cu}-\mathrm{K} \alpha$ radiation $(\lambda=$ $1.5056 \AA$ ) at a scanning rate of $8^{\circ} \mathrm{min}^{-1}$ with a step size of $0.02^{\circ}$ over a $2 \theta$ range of $10-80^{\circ}$. The surface atomic states of the catalysts were analyzed using XPS (Axis Ultra ${ }^{\text {DLD }}$ ) with Al-K $\alpha$ radiation $(h \nu=1486.7 \mathrm{eV}, 225 \mathrm{~W}, 15 \mathrm{~mA}, 15 \mathrm{kV})$. The binding energies were calibrated using the $\mathrm{C} 1 \mathrm{~s}$ peak at $284.5 \mathrm{eV}$ as a reference, and experimental data were fitted with a GaussianLorentzian mixed function as implemented in the Origin software. $\mathrm{H}_{2}$-TPR ( $\mathrm{SO}_{2}$-TPD) was performed using a Chemisorb instrument (Chembet Pulsar TPR/TPD 2139). These tests were conducted using a quartz U-type reactor, which was connected to a thermal conductivity detector. The module reductant gas was composed of $10 \mathrm{vol} \% \mathrm{H}_{2}$ balanced by $\mathrm{Ar}$ at a flow rate of $40 \mathrm{~mL} \mathrm{~min}^{-1}$. Before the reduction, the sample $(100 \mathrm{mg}$ ) was pretreated in a He stream at $300{ }^{\circ} \mathrm{C}$ for $1 \mathrm{~h}$, and then TPR was heated from room temperature to $900{ }^{\circ} \mathrm{C}$ at a rate of $10{ }^{\circ} \mathrm{C} \mathrm{min}^{-1}$. As for the TPD, before the test, the sample (100 mg) was pretreated in a He stream at $300{ }^{\circ} \mathrm{C}$ for $1 \mathrm{~h}$ to eliminate surface impurities. The adsorption of $\mathrm{SO}_{2}$ was performed at room temperature. In this process, the samples were first treated with $\mathrm{SO}_{2}\left(5 \mathrm{vol} \%, 40 \mathrm{~mL} \min ^{-1}\right)$ for $2 \mathrm{~h}$ to reach saturation. Second, samples were purified using $\mathrm{He}$ (40 $\mathrm{mL} \mathrm{min}^{-1}$ ) for $1 \mathrm{~h}$, and then TPD was started at room temperature and heated to $1100{ }^{\circ} \mathrm{C}$ at a rate of $5{ }^{\circ} \mathrm{C} \mathrm{min}{ }^{-1}$.

In situ DRIFTS spectra were recorded from $650 \mathrm{~cm}^{-1}$ to $4000 \mathrm{~cm}^{-1}$ at a spectral resolution of $4 \mathrm{~cm}^{-1}$ (number of scans, 100) on a Nicolet 6700 FTIR spectrophotometer equipped with a high-sensitivity MCT detector cooled by liquid $\mathrm{N}_{2}$. The DRIFTS 
cell (Pike) was fitted with a ZnSe window and heating cartridge, which permits the heating of the sample to $500{ }^{\circ} \mathrm{C}$. Before the performance, all the samples were ground into fine powder $(<2$ $\mu \mathrm{m})$ and diluted with $\mathrm{KBr}$. The dilution factor was approximately 150 . Then the powder (approximately $25 \mathrm{mg}$ ) was placed on a sample holder and carefully flattened for IR reflection. The sample was pretreated with a high-purity Ar stream at $400{ }^{\circ} \mathrm{C}$ for $1 \mathrm{~h}$ to eliminate the physically absorbed water and other impurities. At each target temperature, the sample background was collected during cooling. For the steady state response, at each desired temperature, the sample was exposed to a controlled stream of $200 \mathrm{ppm} \mathrm{SO}_{2}$ and/or $1000 \mathrm{ppm} \mathrm{NO}$ balanced by $\mathrm{Ar}$ at a flow rate of $100 \mathrm{~mL} \mathrm{~min}^{-1}$ for $0.5 \mathrm{~h}$ for saturation. For the transient response, the spectra were continuously collected in synchrony with the reaction time under each desire condition. The spectra were recorded at various target temperatures by subtracting the corresponding background reference.

\subsection{Catalytic activity testing}

The activity of the catalysts was investigated in a fixed-bed reactor system, which consisted of a stainless steel tubular reactor (internal diameter: $12.7 \mathrm{~mm}$ ), a gas supply and flow rate control unit (mass flow meter, Beijing Sevenstar Huachuang Electronics Co., Ltd.), a gas heating unit (Shandong Lulong furnace factory), and a gas analysis unit (GASMET DX4000, Finland). First, $2 \mathrm{~g}$ (approximately $5 \mathrm{~cm}^{3}$ ) of the sample was loaded into the reactor and pretreated with $\mathrm{N}_{2}$ at $300{ }^{\circ} \mathrm{C}$ for $1 \mathrm{~h}$ to activate the samples and eliminate the surface impurities, followed by cooling to room temperature. The total flow rate of the mixed gas was $500 \mathrm{~mL} \min ^{-1}\left(\mathrm{GHSV}=6000 \mathrm{~h}^{-1}\right)$. The modeled flue gas was nitrogen, $1 \% \mathrm{NO}$ balanced by $\mathrm{N}_{2}, 2 \% \mathrm{CO}$ balanced by $\mathrm{N}_{2}$, and 5000 ppm $\mathrm{SO}_{2}$ balanced by $\mathrm{N}_{2}$ (Deyang Gas, Ltd.). Tests under each reaction condition were completed after more than $1 \mathrm{~h}$, until a steady state had been reached, and the data were collected after the outlet concentration had reached a steady state. The NO conversion and $\mathrm{N}_{2} \mathrm{O}$ selectivity were calculated from concentrations of the inlet and outlet flue gases using eqn (1).

$$
\begin{aligned}
& \mathrm{NO} \text { conversion }=\frac{[\mathrm{NO}]_{\text {in }}-[\mathrm{NO}]_{\text {out }}}{[\mathrm{NO}]_{\text {in }}} \times 100 \% \\
& \mathrm{~N}_{2} \mathrm{O} \text { selectivity }=\frac{2 \times \mathrm{N}_{2} \mathrm{O}_{\text {out }}}{\mathrm{NO}_{x, \text { in }}-\mathrm{NO}_{x, \text { out }}} \times 100 \%
\end{aligned}
$$

\section{Results and discussion}

\subsection{Catalytic activity}

DeNO efficiency is an important factor for evaluating the catalyst activity. Therefore, we determined the deNO efficiency of the prepared catalysts, and the results are displayed in Fig. $\mathrm{S} 2 \dagger$ and 1 . As shown in Fig. $\mathrm{S} 2(\mathrm{a}), \dagger$ it can be observed that $\mathrm{Fe}_{0.8} \mathrm{Co}_{0.2} /$ ASC exhibits excellent deNO performance in the temperature range of $150-300{ }^{\circ} \mathrm{C}$. At $150{ }^{\circ} \mathrm{C}$, the $\mathrm{NO}$ conversion has reached to approximate $50 \%$. When the temperature is above $200{ }^{\circ} \mathrm{C}$, the conversion remains at a steady state: approximately $96-98 \%$. With the addition of cerium oxides, the deNO efficiency obviously decreases. The sample $\mathrm{Fe}_{0.8} \mathrm{Co}_{0.2} \mathrm{Ce}_{0.05} / \mathrm{ASC}$ shows the lowest NO conversion. In the temperature range of $150-250{ }^{\circ} \mathrm{C}$, the NO conversion for $\mathrm{Fe}_{0.8} \mathrm{Co}_{0.2} \mathrm{Ce}_{0.05} / \mathrm{ASC}$ is about $80 \%$ of that for $\mathrm{Fe}_{0.8} \mathrm{Co}_{0.2} /$ ASC. Moreover, the efficiency for $\mathrm{Fe}_{0.8} \mathrm{Co}_{0.2} \mathrm{Ce}_{0.1} /$ ASC and $\mathrm{Fe}_{0.8} \mathrm{Co}_{0.2} \mathrm{Ce}_{0.2} / \mathrm{ASC}$ is in between. As we previously proposed, ${ }^{5}$ the excellent deNO efficiency depends on the optimizing crystalline cell and the interaction of $\mathrm{Fe}-\mathrm{Co}$. It is speculated from the decrease of NO conversion, that Ce addition can affect the optimization of the Fe-Co crystalline cell to some extent. This could be established by analysis of the ICP results: the doping of Ce induces variation of the loading of $\mathrm{Fe}$ and $\mathrm{Co}$ (in Table $\mathrm{S} 1 \dagger$ ). Moreover, it can be observed that the molar ratio of $\mathrm{Fe}: \mathrm{Co}$ for $\mathrm{Fe}_{0.8} \mathrm{Co}_{0.2} \mathrm{Ce}_{0.1} / \mathrm{ASC}$ is very close to that of $\mathrm{Fe}_{0.8} \mathrm{Co}_{0.2} / \mathrm{ASC}$, which should be responsible for the excellent deNO activity. Fig. $\mathrm{S} 2(\mathrm{~b}) \dagger$ shows the $\mathrm{N}_{2} \mathrm{O}$ selectivity of the prepared catalysts. It can be observed that Ce addition to the surface of ASC can increase the degree of $\mathrm{N}_{2} \mathrm{O}$ selectivity in the range of $150-200{ }^{\circ} \mathrm{C}$. This is corresponding to that of NO conversion testing, i.e., at low temperature, low NO conversion indicating the high $\mathrm{N}_{2} \mathrm{O}$ selectivity. ${ }^{27}$ However, as the temperature increases, the $\mathrm{N}_{2} \mathrm{O}$ will be decomposed to $\mathrm{N}_{2}$.
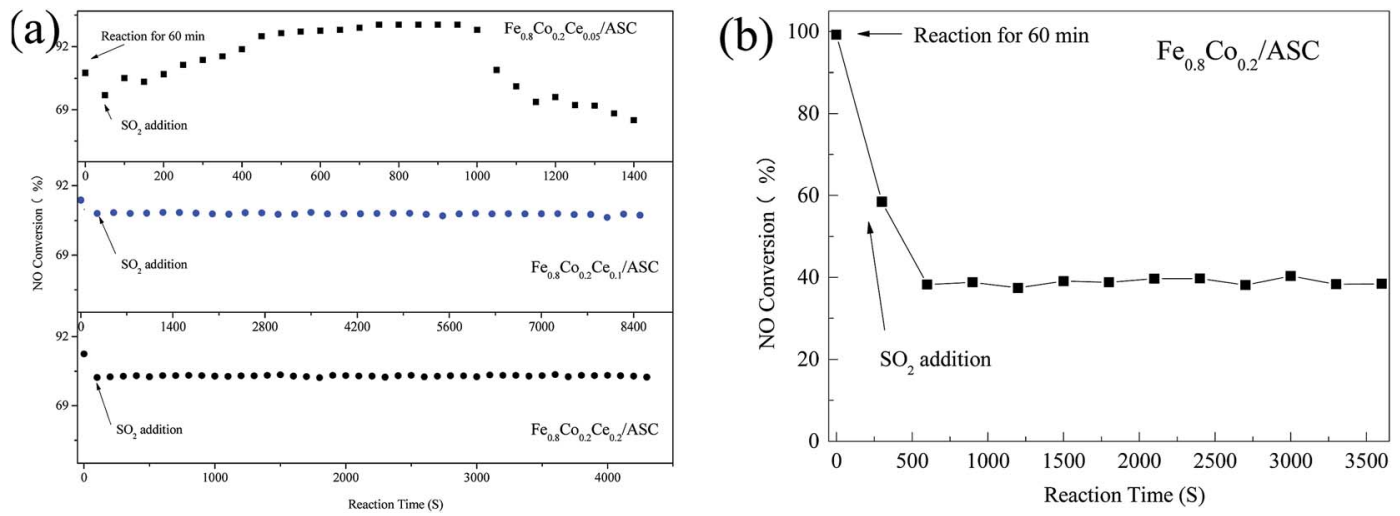

Fig. $1 \mathrm{NO}$ conversion of catalysts. Reaction conditions: 2000 ppm CO, 1000 ppm NO, 200 ppm SO 2 and balance by $\mathrm{N}_{2}$, at $250{ }^{\circ} \mathrm{C}, \mathrm{GHSV}=$ $6000 \mathrm{~h}^{-1}$ 


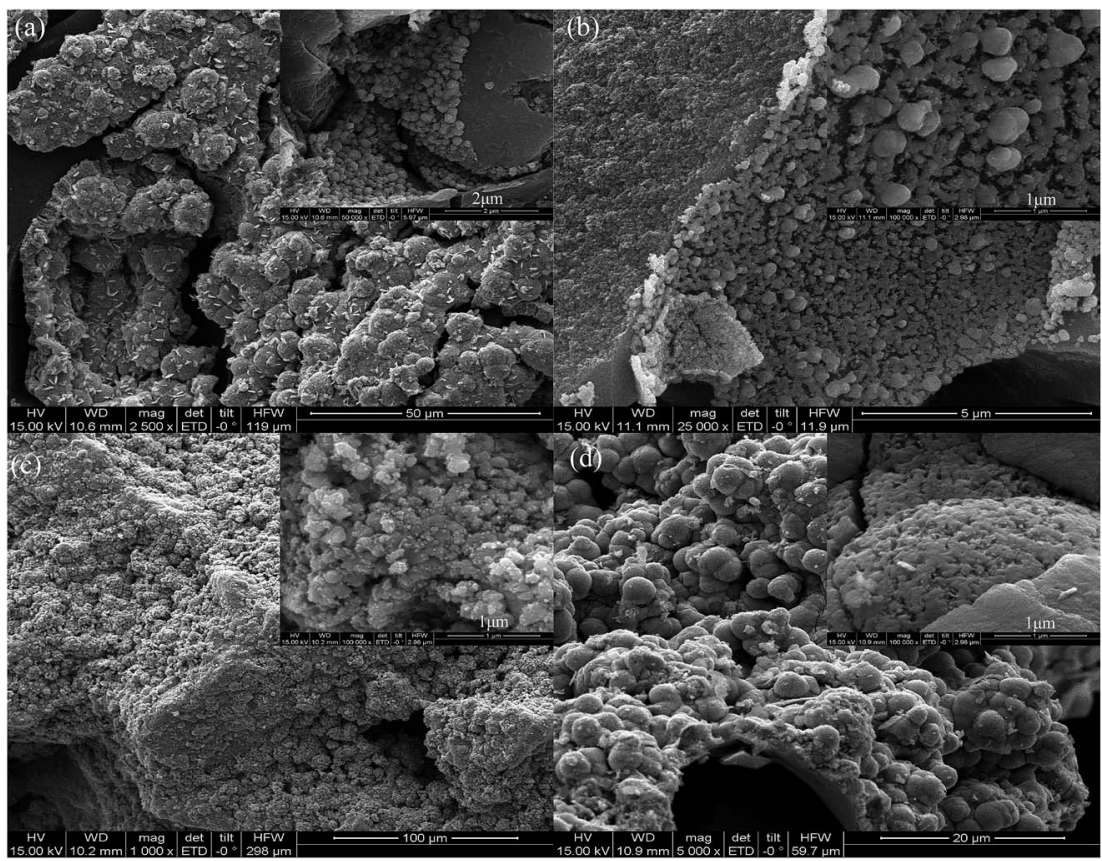

Fig. 2 SEM images of catalysts: (a) $\mathrm{Fe}_{0.8} \mathrm{Co}_{0.2} / \mathrm{ASC}$; (b) $\mathrm{Fe}_{0.8} \mathrm{Co}_{0.2} \mathrm{Ce}_{0.05} / \mathrm{ASC}$; (c) $\mathrm{Fe}_{0.8} \mathrm{Co}_{0.2} \mathrm{Ce}_{0.1} / \mathrm{ASC}$ (d) $\mathrm{Fe}_{0.8} \mathrm{Co}_{0.2} \mathrm{Ce}_{0.2} / \mathrm{ASC}$

Although, the addition of cerium oxides can reduce the deNO efficiency, the $\mathrm{SO}_{2}$ resistance of the catalysts doped by Ce increases. Fig. 1 shows the effect of $\mathrm{SO}_{2}$ on the deNO activity. It can be found that for $\mathrm{Fe}_{0.8} \mathrm{Co}_{0.2} \mathrm{Ce}_{0.05} / \mathrm{ASC}$, when $200 \mathrm{ppm}$ of $\mathrm{SO}_{2}$ is introduced into the dry flue gas, the NO conversion first decreases and then increases: $\sim 80 \% \rightarrow \sim 70 \% \rightarrow \sim 95 \%$ (in Fig. 1(a)). The first decreasing is speculated to be ascribed to the competitive adsorption between $\mathrm{SO}_{2}$ and $\mathrm{NO}$, according to the previous literature. After $1000 \mathrm{~s}$ of reaction, the NO conversion begins to decrease until reaching steady state at $\sim 55 \%$; whereas, the $\mathrm{SO}_{2}$ resistance for $\mathrm{Fe}_{0.8} \mathrm{Co}_{0.2} \mathrm{Ce}_{0.1} / \mathrm{ASC}$ and $\mathrm{Fe}_{0.8} \mathrm{Co}_{0.2} \mathrm{Ce}_{0.2} / \mathrm{ASC}$ are similar. After introduction of $\mathrm{SO}_{2}$, the $\mathrm{NO}$ conversion slightly decreases; then remains steady. For $\mathrm{Fe}_{0.8} \mathrm{Co}_{0.2} \mathrm{Ce}_{0.1} / \mathrm{ASC}$, the steady conversion rate is approximately $80 \%$, while that for $\mathrm{Fe}_{0.8} \mathrm{Co}_{0.2} \mathrm{Ce}_{0.2} / \mathrm{ASC}$ is $\sim 75 \%$. When the Ce doped samples are compared with $\mathrm{Fe}_{0.8} \mathrm{Co}_{0.2} / \mathrm{ASC}$ (Fig. 1(b)), it is easy to see that the doping of cerium oxides can improve the $\mathrm{SO}_{2}$ tolerance.

As for the reason for the $\mathrm{SO}_{2}$ tolerance improvement, it is speculated that a small amount of cerium oxide $\left(\mathrm{Fe}_{0.8} \mathrm{Co}_{0.2} \mathrm{Ce}_{0.05} /\right.$ ASC) may induce gaseous $\mathrm{SO}_{2}$ to adsorb to its surface. The adsorbed $\mathrm{SO}_{x}$ can generate some acid sites beneficial for the reaction of $\mathrm{NO}+\mathrm{CO}$. Nevertheless, when the amount of adsorbed $\mathrm{SO}_{x}$ increases to a threshold degree, surface sulfates may be produced that will result in the decrease of NO conversion. With the doping amount of cerium oxides increasing, the adsorbed $\mathrm{SO}_{x}$ may transform to bulk-like sulfates ${ }^{1,2}$ on $\mathrm{CeO}_{2}$ that will have little influence on the active components ( $\mathrm{Fe}$ and $\mathrm{Co}$ ). The evident mechanism will be discussed in the Characterization section.

\subsection{Surface morphology and textural parameters of the prepared catalysts}

Fig. 2 displays the SEM images of the samples, viz., $\mathrm{Fe}_{0.8} \mathrm{Co}_{0.2} /$ ASC and the Ce doped catalysts. As shown in Fig. 2(a), it can be observed that uniform spherical clusters are produced on the surface of $\mathrm{Fe}_{0.8} \mathrm{Co}_{0.2} / \mathrm{ASC}$. With the doping of Ce, the sizes of the clusters begin to differentiate (Fig. 2(b)). When the molar ratio of cerium is $\geq 0.1$, a very obvious accumulation phenomenon is observed. That is, the spherical clusters serry on the surface of ASC (Fig. 2(c)). Moreover, as the ratio is equal to 0.2, a block-like structure appears on the surface (Fig. 2(d)). It is speculated that with the increasing of the loaded metal oxides, the ACS surface structure will be occupied by the metal crystal. The reduction of the available surface area leads to an accumulation phenomenon. The results in surface morphology that is very similar to that in the $\mathrm{N}_{2}$ physisorption. Table 2 summarizes the textural parameters of the prepared catalysts. It can be observed that the average pore size and surface area decrease obviously with increase in the loading amount of the cerium oxides. However, as the molar ratio of cerium is 0.1 , the value of the average pore volume increases to $0.61 \mathrm{~cm}^{3} \mathrm{~g}^{-1}$. Maybe this is responsible for the improvement of the $\mathrm{SO}_{2}$ tolerance.

\subsection{XRD analysis of the prepared catalysts}

In order to obtain the correlation of the $\mathrm{SO}_{2}$ tolerance with the surface metal crystal, XRD was performed. Fig. 3 shows the XRD

Table 2 Textural properties of catalysts

\begin{tabular}{llll}
\hline Catalysts & $\begin{array}{l}\text { Average pore } \\
\text { width }(\mathrm{nm})\end{array}$ & $\begin{array}{l}\text { Pore volume } \\
\left(\mathrm{cm}^{3} \mathrm{~g}^{-1}\right)\end{array}$ & $\begin{array}{l}\text { Specific surface } \\
\text { area }\left(\mathrm{m}^{2} \mathrm{~g}^{-1}\right)\end{array}$ \\
\hline $\mathrm{Fe}_{0.8} \mathrm{Co}_{0.2} / \mathrm{ASC}$ & 2.14 & 0.59 & 272.096 \\
$\mathrm{Fe}_{0.8} \mathrm{Co}_{0.2} \mathrm{Ce}_{0.05} / \mathrm{ASC}$ & 2.08 & 0.56 & 263.021 \\
$\mathrm{Fe}_{0.8} \mathrm{Co}_{0.2} \mathrm{Ce}_{0.1} / \mathrm{ASC}$ & 1.94 & 0.61 & 259.996 \\
$\mathrm{Fe}_{0.8} \mathrm{Co}_{0.2} \mathrm{Ce}_{02} / \mathrm{ASC}$ & 1.83 & 0.57 & 233.986
\end{tabular}




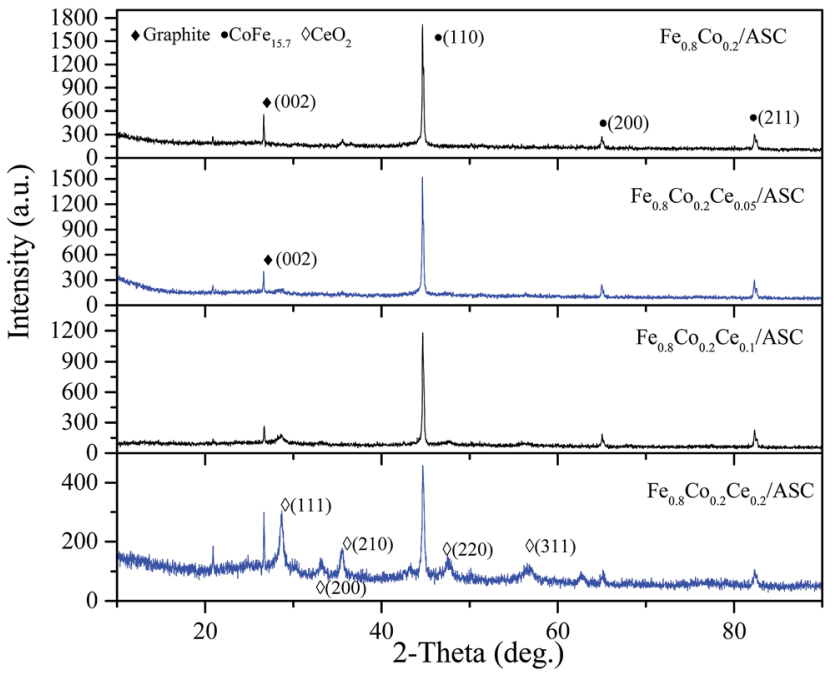

Fig. 3 XRD patterns of catalysts.

patterns of the catalysts. As shown in Fig. 3, for all samples, a diffraction peak is observed at approximately $25-30^{\circ}$, which is a peak characteristic of the (002) crystal face of graphite (JCPDF =13-0148). In addition, a characteristic peak (at approximate $45^{\circ}$ ) for the (110) crystal face of $\mathrm{CoFe}_{15.7}(\mathrm{JCPDF}=65-7519)$ is found for these four samples. This indicates that the major active component ( $\mathrm{CoFe}_{15.7}$ (ref. 5)) is not changed by the doping of Ce. Notably, it can be also observed that there are no characteristic peaks of cerium oxides when the molar ratio of Ce is 0.05 . When the ratio increases to 0.1 , a peak appears at approximately $28^{\circ}$, which should be assigned to the characteristic peak for the (111) crystal face of $\mathrm{CeO}_{2}(\mathrm{JCPDF}=82-0661)$. Moreover, the intensity of this peak increases to some extent with the loading amount of $\mathrm{CeO}_{2}$. As the ratio of Ce is 0.2 , the sample shows the characteristic peaks for the (200), (220), and (311) crystal faces of $\mathrm{CeO}_{2}$. Comparing the degree of the intensity for the (110) crystal face of $\mathrm{CoFe}_{15.7}$, it can be observed

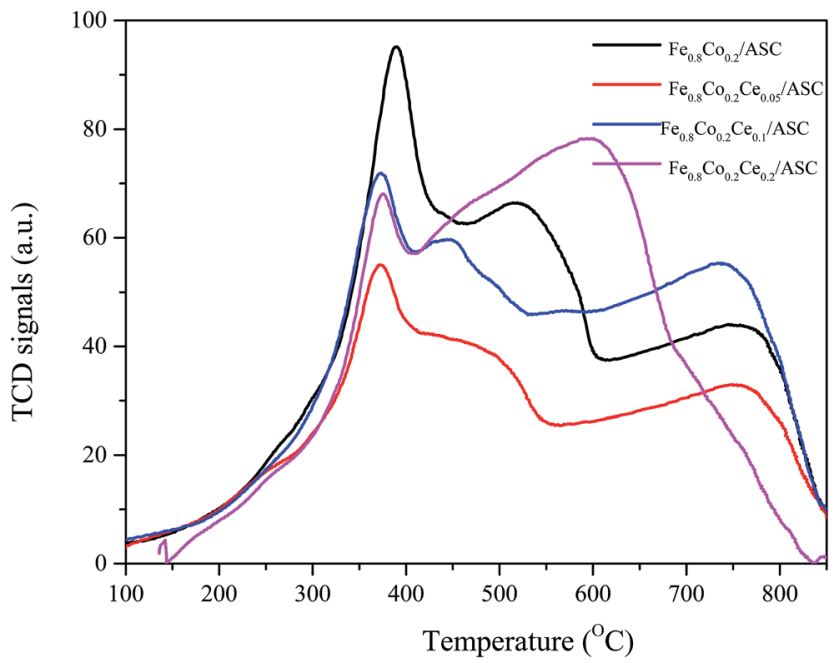

Fig. $4 \quad \mathrm{H}_{2}$-TPR profiles of catalysts. that the introduction of Ce can reduce the intensity of this peak. That indicates the crystallization properties of $\mathrm{CoFe}_{15.7}$ are diminished. This is speculated to be responsible for the slight decrease in the deNO activity.

\section{4 $\quad \mathrm{H}_{2}$-TPR and $\mathrm{SO}_{2}$-TPD analysis}

$\mathrm{H}_{2}$-TPR is performed to investigate the reduction behavior of the catalyst surface components. Fig. 4 shows the TPR profiles of the prepared catalysts. It can be observed that for all samples, there is a main peak at approximately $378^{\circ} \mathrm{C}$. As we previously determined, this peak should be attributed to the interaction of Fe and Co oxides. ${ }^{5,41,42}$ This result corresponds to the XRD analysis results (i.e., the major active component is $\mathrm{CoFe}_{15.7}$ ). Additionally, along with the main peak, a shoulder peak is observed for each of the four samples. We can also see that the addition of Ce could change the position of this peak to a lower temperature. For $\mathrm{Fe}_{0.8} \mathrm{Co}_{0.2} / \mathrm{ASC}$, the broad shoulder peak appears at approximate $520{ }^{\circ} \mathrm{C}$, while for $\mathrm{Fe}_{0.8} \mathrm{Co}_{0.2} \mathrm{Ce}_{0.1} / \mathrm{ASC}$, the central temperature of this peak is about $450{ }^{\circ} \mathrm{C}$. It is speculated that the doping of Ce into the $\mathrm{Fe}-\mathrm{Co}$ binary oxides can improve the activity of the low valent transition metal. However, for $\mathrm{Fe}_{0.8} \mathrm{Co}_{0.2} \mathrm{Ce}_{0.2} / \mathrm{ASC}$, this shoulder peak is mixed with a higher temperature peak. This overlap peak can be decomposed into two peaks: one at approximate $450{ }^{\circ} \mathrm{C}$; the other at $625{ }^{\circ} \mathrm{C}$. For the other three samples, the highest temperature peak appears at $\sim 780{ }^{\circ} \mathrm{C}$. It is speculated that this peak is assignable to the complex components of solid carbon and metal oxides, while for $\mathrm{Fe}_{0.8} \mathrm{Co}_{0.2} \mathrm{Ce}_{0.2} / \mathrm{ASC}$, the peak at $625{ }^{\circ} \mathrm{C}$ should be ascribed to the excellent redox performance of $\mathrm{CeO}_{2}$. In conclusion, it can be seen that Ce doping can improve the reduction behavior of the low valent metal cation, which may be beneficial for $\mathrm{SO}_{2}$ tolerance.

$\mathrm{SO}_{2}$-TPD is a significant method for investigating the $\mathrm{SO}_{2}$ resistance of CO-deNO catalysts. Fig. 5 shows the TPD profiles of the prepared catalysts. It is observable that for $\mathrm{Fe}_{0.8} \mathrm{Co}_{0.2} / \mathrm{ASC}$, a main peak appears at approximately $850{ }^{\circ} \mathrm{C}$. Along with the main peak, a broad weaker peak is also detected at $\sim 130^{\circ} \mathrm{C}$. As reported ${ }^{43}$ the ferric sulfates has a decomposition temperature of $600-800{ }^{\circ} \mathrm{C}$, while the temperature for the cobalt sulfates is approximately $1200^{\circ} \mathrm{C}$. According to our previous research, ${ }^{5}$ the interaction between $\mathrm{Fe}$ and Co changes the position of the main peak to $\sim 850{ }^{\circ} \mathrm{C}$. The low temperature peak should be ascribed to desorption of coordinated $\mathrm{SO}_{2}$. Furthermore, for the other three samples, similar peaks are observed. However, the central temperatures of these peaks show some differentiation. It is easily seen that the position of the low temperature peak shifts to the left with the introduction of Ce at approximately $100{ }^{\circ} \mathrm{C}$. This phenomenon indicates that $\mathrm{CeO}_{2}$ on the surface could improve desorption of coordinated $\mathrm{SO}_{2}$. Besides, the intensity of the low temperature peak for $\mathrm{Fe}_{0.8} \mathrm{Co}_{0.2} \mathrm{Ce}_{0.05} / \mathrm{ASC}$ is stronger than that for other two catalysts, this demonstrated there is more amount of $\mathrm{SO}_{2}$ adsorbing, i.e. the competitive adsorption of $\mathrm{NO}+\mathrm{SO}_{2}$ inevitably exists in the initial seconds. However, the high temperature peak shows a reverse trend (i.e., the central temperature shifts to the right). For $\mathrm{Fe}_{0.8} \mathrm{Co}_{0.2} \mathrm{Ce}_{0.05} / \mathrm{ASC}$, the temperature of the peak's maximum is $\sim 880{ }^{\circ} \mathrm{C}$, while this 

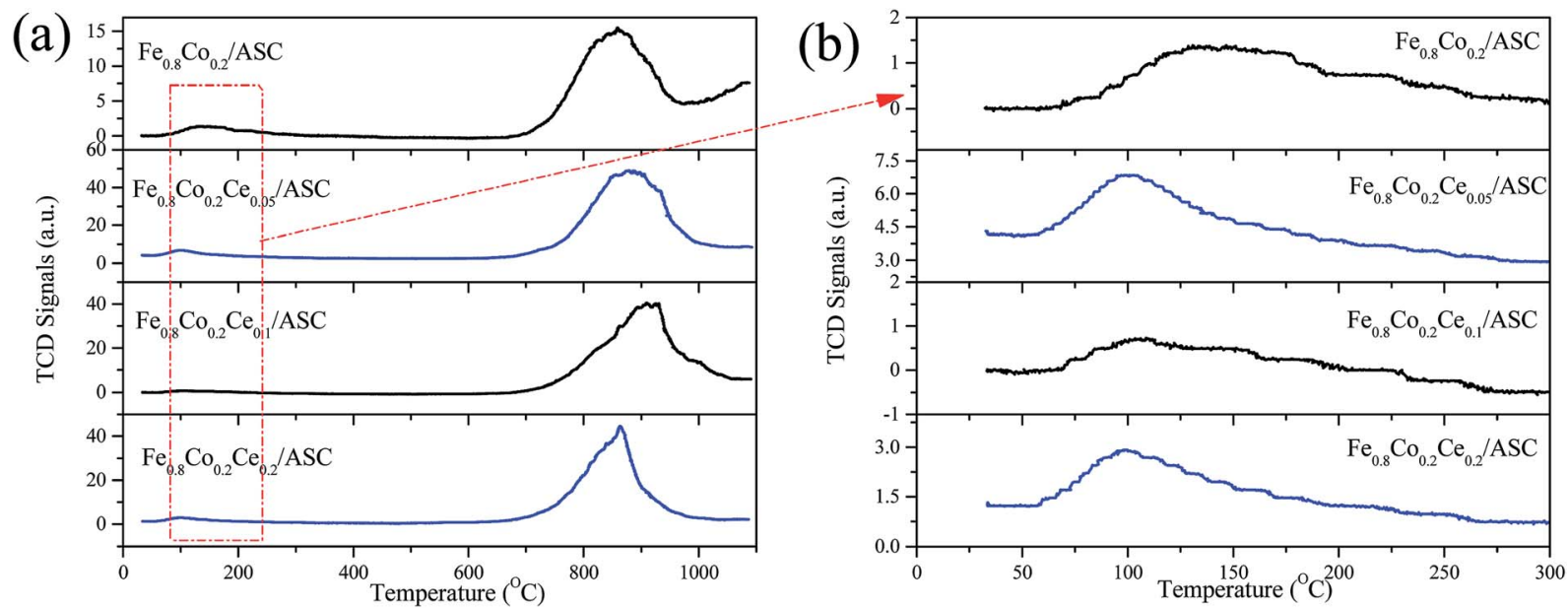

Fig. $5 \mathrm{SO}_{2}$-TPD profiles of catalysts.

temperature shifts to $\sim 910{ }^{\circ} \mathrm{C}$ for $\mathrm{Fe}_{0.8} \mathrm{Co}_{0.2} \mathrm{Ce}_{0.1} /$ ASC. Nevertheless, when Ce molar ratio increases to 0.2 , this temperature shifts to $850{ }^{\circ} \mathrm{C}$. As reported in the literatures, ${ }^{33,44,45} \mathrm{Ce}\left(\mathrm{SO}_{4}\right)_{2}$ shows a decomposition peak at approximate $750{ }^{\circ} \mathrm{C}$, while $\mathrm{Ce}_{2}\left(\mathrm{SO}_{4}\right)_{3}$ has decomposition peaks at $900{ }^{\circ} \mathrm{C}$. Therefore, we can speculate that when Ce is added into the catalyst, it will introduce some interactions among the metals. These interactions will produce different kinds of sulfates with $\mathrm{SO}_{2}$ added into the flue gas. Compared the decomposition temperature of the sulfates, it is reasonable to demonstrate that the left shift is
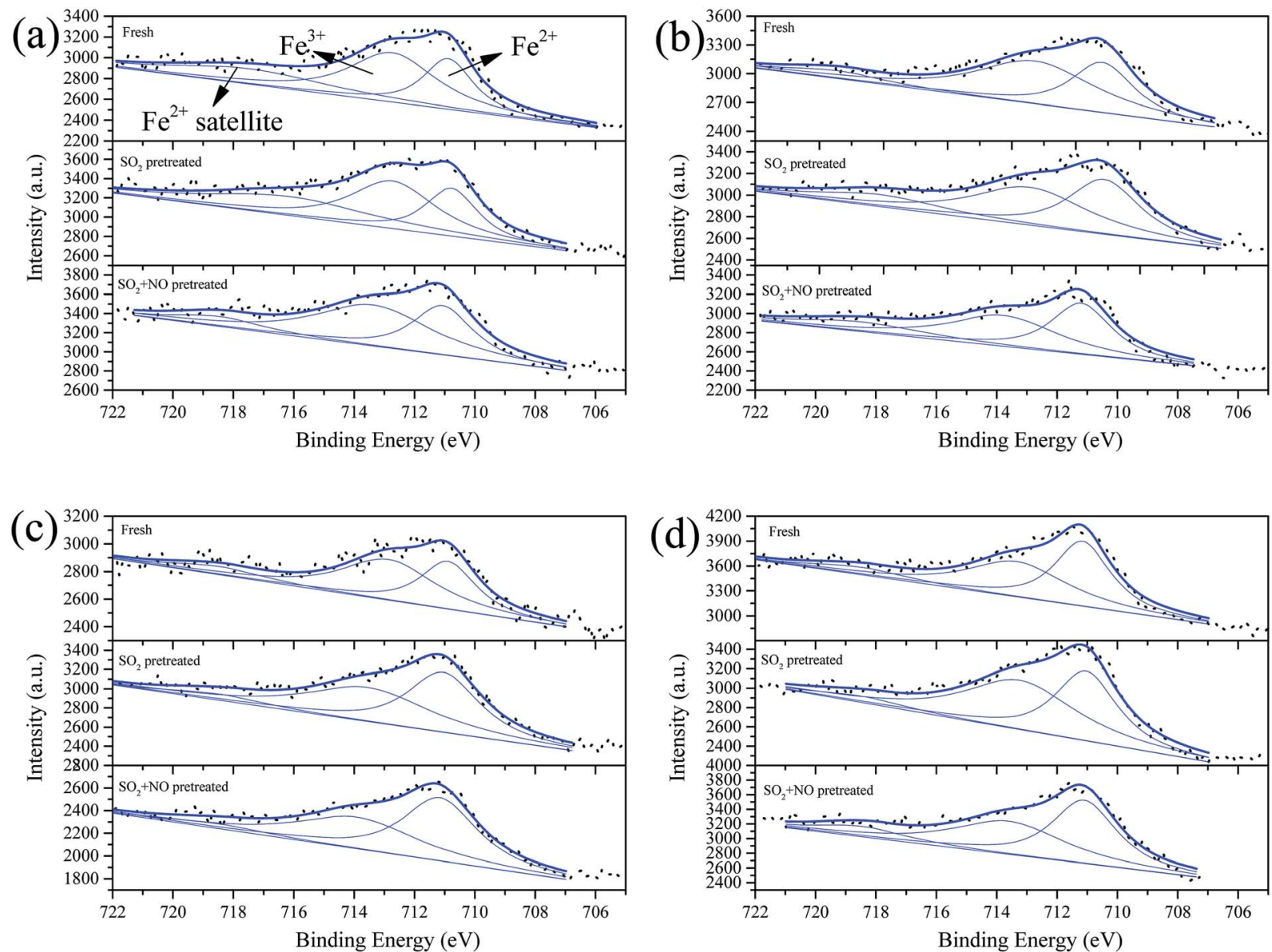

Fig. $6 \mathrm{Fe} 2 \mathrm{p}_{3 / 2}$ from XPS spectra of catalysts (a) $\mathrm{Fe}_{0.8} \mathrm{Co}_{0.2} / \mathrm{ASC}$, (b) $\mathrm{Fe}_{0.8} \mathrm{Co}_{0.2} \mathrm{Ce}_{0.05} / \mathrm{ASC}$, (c) $\mathrm{Fe}_{0.8} \mathrm{Co}_{0.2} \mathrm{Ce}_{0.1} / \mathrm{ASC}$, and (d) $\mathrm{Fe}_{0.8} \mathrm{Co}_{0.2} \mathrm{Ce}_{0.2} / \mathrm{ASC}$, with different treatment. 

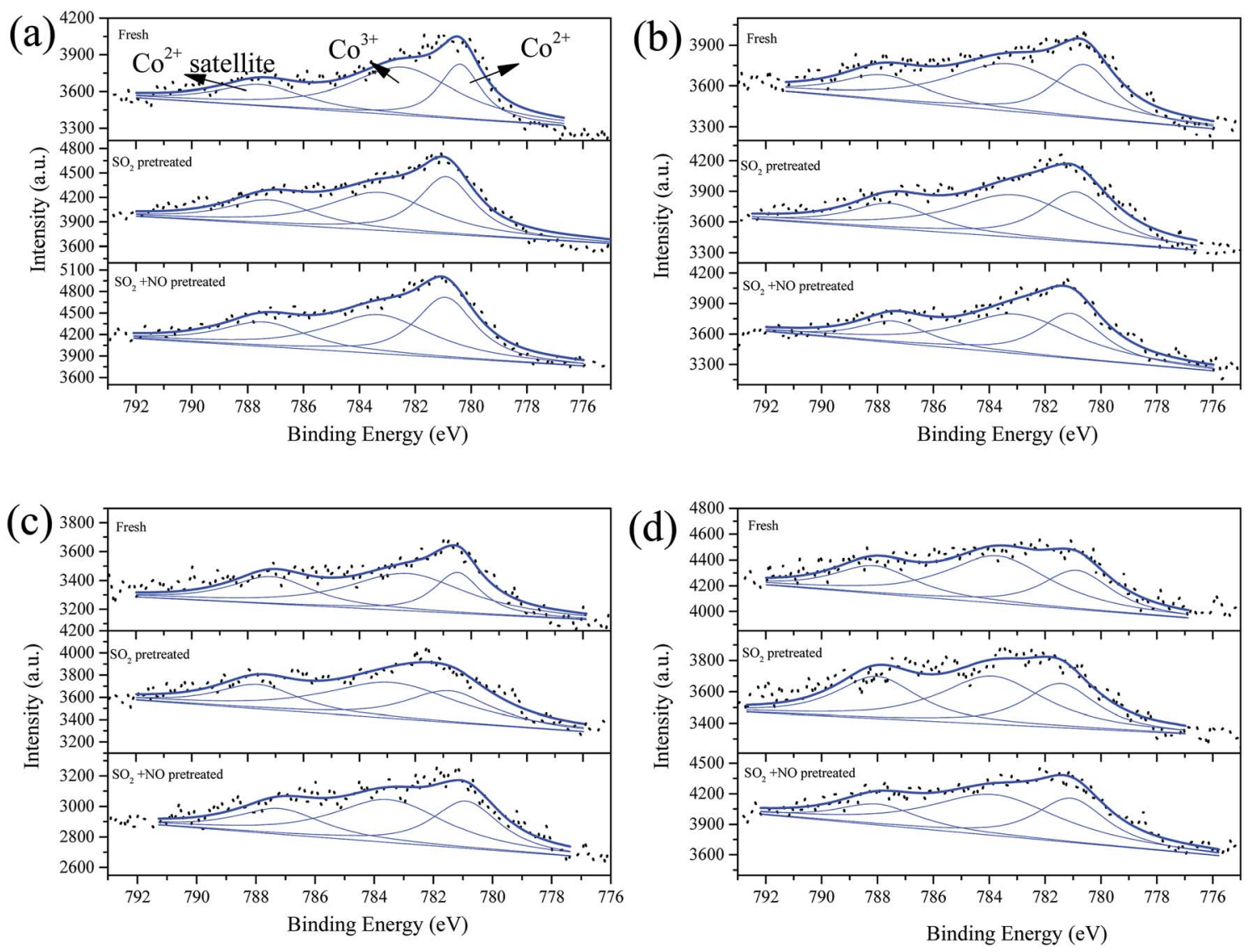

Fig. $7 \mathrm{Co} 2 \mathrm{p}_{3 / 2}$ from XPS spectra of catalysts (a) $\mathrm{Fe}_{0.8} \mathrm{Co}_{0.2} / \mathrm{ASC}$, (b) $\mathrm{Fe}_{0.8} \mathrm{Co}_{0.2} \mathrm{Ce}_{0.05} / \mathrm{ASC}$, (c) $\mathrm{Fe}_{0.8} \mathrm{Co}_{0.2} \mathrm{Ce}_{0.1} / \mathrm{ASC}$ and (d) $\mathrm{Fe}_{0.8} \mathrm{Co}_{0.2} \mathrm{Ce}_{0.2} / \mathrm{ASC}$, with different treatment.

attributed to the generation of $\mathrm{Ce}_{2}\left(\mathrm{SO}_{4}\right)_{3}$. The abnormal phenomenon for $\mathrm{Fe}_{0.8} \mathrm{Co}_{0.2} \mathrm{Ce}_{0.2} / \mathrm{ASC}$ is attributed to the interaction between $\mathrm{Ce}\left(\mathrm{SO}_{4}\right)_{2}$ and $\mathrm{Ce}_{2}\left(\mathrm{SO}_{4}\right)_{3}$, because on the surface of $\mathrm{Fe}_{0.8} \mathrm{Co}_{0.2} \mathrm{Ce}_{0.2} / \mathrm{ASC}$, there should be more kinds of cerium sulfates. Owing to the excellent thermal stability, and rejection for $\mathrm{SO}_{2}, \mathrm{Ce}_{2}\left(\mathrm{SO}_{4}\right)_{2}$ has been proved to improve $\mathrm{SO}_{2}$ resistance of the catalysts. ${ }^{2,33}$ Moreover, in the atmosphere of simulated flue gas, the generation of $\mathrm{Ce}_{2}\left(\mathrm{SO}_{4}\right)_{3}$ occurs faster. Therefore, we speculate that on the surface of $\mathrm{Fe}_{0.8} \mathrm{Co}_{0.2} \mathrm{Ce}_{0.1} / \mathrm{ASC}$, there is a larger amount of $\mathrm{Ce}_{2}\left(\mathrm{SO}_{4}\right)_{3}$. The rapidly generated $\mathrm{Ce}_{2}\left(\mathrm{SO}_{4}\right)_{3}$ could inhibit the $\mathrm{SO}_{2}$ poisoning of the active components.

\subsection{XPS analysis}

To demonstrate the opinion we obtained in Section 3.4, we carried out XPS on the surface components. Fig. 6-9 show the XPS results of $\mathrm{Fe}, \mathrm{Co}, \mathrm{Ce}$, and $\mathrm{S}$; and in addition, the percentages of the surface components are summarized in Table S3. $\dagger$ In these figures, the label "Fresh" indicates catalysts without pretreatment, the label " $\mathrm{SO}_{2}$-pretreated" represents samples purged with $200 \mathrm{ppm}$ of $\mathrm{SO}_{2}$ for $1 \mathrm{~h}$ at $250^{\circ} \mathrm{C}$, and the label " $\mathrm{SO}_{2}$ + NO" indicates samples pretreated by $200 \mathrm{ppm} \mathrm{SO}_{2}+1000 \mathrm{ppm}$ $\mathrm{NO}$ for $1 \mathrm{~h}$ at $250{ }^{\circ} \mathrm{C}$. As shown in Fig. 6, we decomposed the overlapped peaks into three, viz. $\mathrm{Fe}^{3+}$ at approximate $713.5 \mathrm{eV}$, $\mathrm{Fe}^{2+}$ at $\sim 711 \mathrm{eV}$, and the satellite peak of $\mathrm{Fe}^{2+}$ at $\sim 718.5 \mathrm{eV}^{46-48}$
It can be observed that for the $\mathrm{Fe}_{0.8} \mathrm{Co}_{0.2} / \mathrm{ASC}$, the percentage of the significant component- $\mathrm{Fe}^{3+}$ is about $46.49 \%$. Moreover, this percentage first increases and then shows a trend of decrease with increasing amount of Ce loaded. This is because even a small amount of Ce can induce an increase in the oxygen releasing performance, while a larger amount of $\mathrm{Ce}$ will generate more cerium oxide crystals. The producing of crystals can consume the oxidation performance. The $\mathrm{SO}_{2}$ pretreatment of the catalysts results in a decrease of the $\mathrm{Fe}^{3+}$ percentage for $\mathrm{Fe}_{0.8} \mathrm{Co}_{0.2} / \mathrm{ASC}, \mathrm{Fe}_{0.8} \mathrm{Co}_{0.2} \mathrm{Ce}_{0.05} / \mathrm{ASC}$, and $\mathrm{Fe}_{0.8} \mathrm{Co}_{0.2} \mathrm{Ce}_{0.1} / \mathrm{ASC}$, but an increment for $\mathrm{Fe}_{0.8} \mathrm{Co}_{0.2} \mathrm{Ce}_{0.2} / \mathrm{ASC}$. It is speculated that the sulfates on the surface can attract some electrons from $\mathrm{FeO}_{x}$. However, with increasing load of cerium, larger amounts of electrons will come from $\mathrm{CeO}_{2}$, due to its excellent redox performance.

The co-addition of $\mathrm{SO}_{2}$ and $\mathrm{NO}$ to the reaction gas can induce an obvious decrease in the $\mathrm{Fe}^{3+}$ percentage for all samples, and may demonstrate that the presence of NO can promote the generation of $\mathrm{SO}_{4}{ }^{2-}$. Similarly, the Co $2 \mathrm{p}_{3 / 2}$ overlapped curves were also decomposed into three peaks: $\mathrm{Co}^{3+}(783.5 \mathrm{eV}), \mathrm{Co}^{2+}$ $(\sim 781 \mathrm{eV})$, and $\mathrm{Co}^{2+}$ satellite peak $(\sim 788 \mathrm{eV}) \cdot{ }^{49,50}$ However, the percentages of $\mathrm{Co}^{3+}$ under different treatments remains stable for all samples (i.e., for the single sample, $\mathrm{SO}_{2}$ or $\mathrm{NO}+\mathrm{SO}_{2}$ atmosphere has almost no influence on the percentage of $\mathrm{Co}^{3+}$ ). Otherwise, the addition of Ce can increase this percentage to 

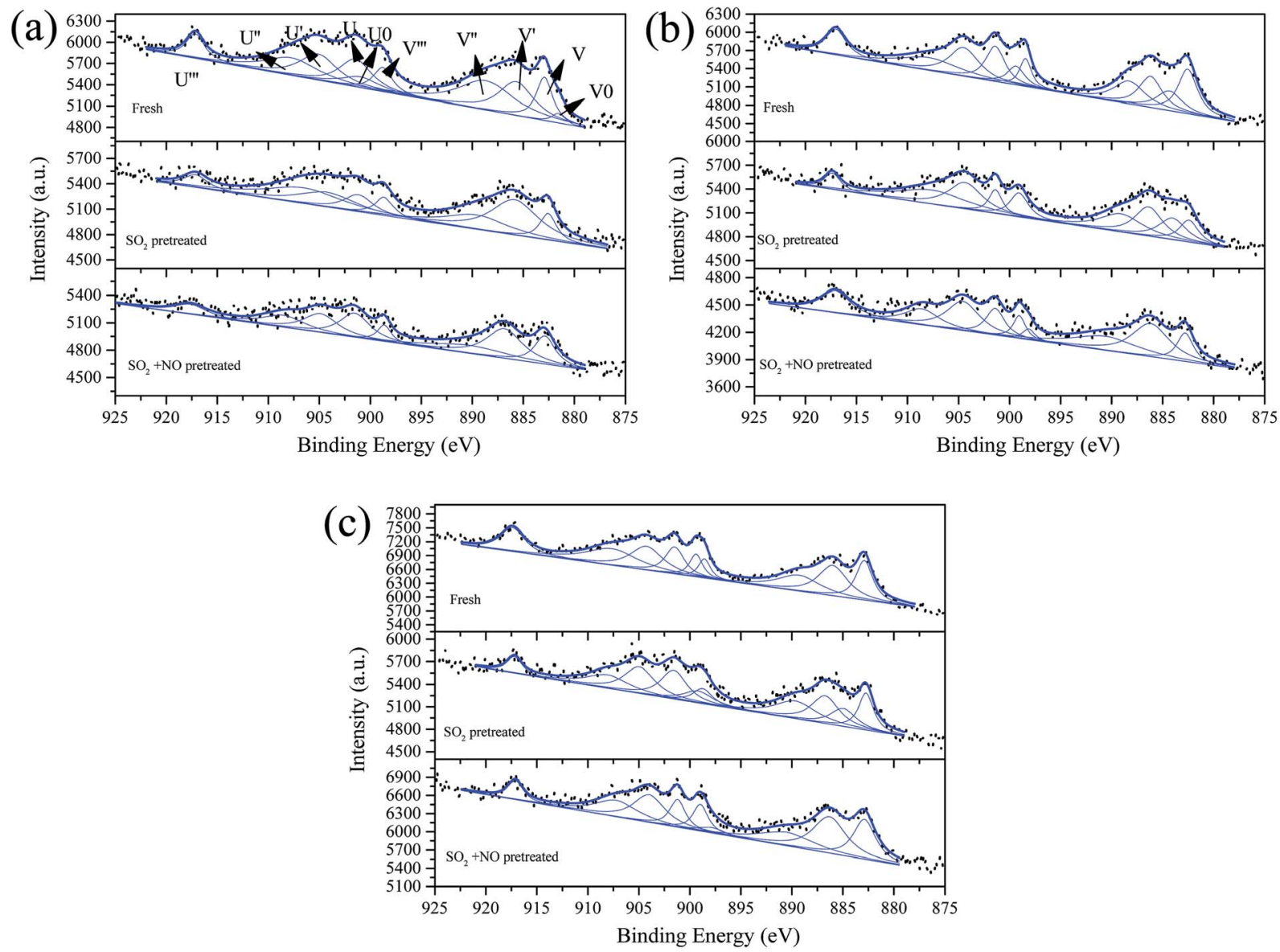

Fig. $8 \mathrm{Ce} 3 \mathrm{~d}$ from XPS spectra of catalysts (a) $\mathrm{Fe}_{0.8} \mathrm{Co}_{0.2} \mathrm{Ce}_{0.05} / \mathrm{ASC}$, (b) $\mathrm{Fe}_{0.8} \mathrm{Co}_{0.2} \mathrm{Ce}_{0.1} / \mathrm{ASC}$, and (c) $\mathrm{Fe}_{0.8} \mathrm{Co}_{0.2} \mathrm{Ce}_{0.2} / \mathrm{ASC}$, with different treatment.

some extent. Therefore, it is reasonable to establish that the poisoning mechanism of $\mathrm{SO}_{2}$ to $\mathrm{Fe}-\mathrm{Co}$ catalysts is the decomposition of $\mathrm{Fe}-\mathrm{Co}$ crystal. The decomposition is ascribed to the interaction of $\mathrm{Fe}^{3+}$ and $\mathrm{SO}_{4}{ }^{2-}$.

Fig. 8 shows the Ce $3 \mathrm{~d}$ curves of the prepared catalysts, and the binding energies of Ce $3 \mathrm{~d}_{5 / 2}$ and $\mathrm{Ce} 3 \mathrm{~d}_{3 / 2}$ are summarized in Table S2..$^{28}$ It can be observed for fresh $\mathrm{Fe}_{0.8} \mathrm{Co}_{0.2} \mathrm{Ce}_{0.05} / \mathrm{ASC}$, that the percentage of $\mathrm{Ce}^{3+}$ is approximate $38.71 \%$. When the molar ratio of $\mathrm{Ce}$ is 0.1 , the $\mathrm{Ce}^{3+}$ percentage increases to $43.91 \%$. However, if the molar ratio continues to increase, the percentage begins to decrease. Thus, it is established that the optimizing loading ratio of Ce is approximate 0.1. Furthermore, the pretreatment of $\mathrm{SO}_{2}$ and $\mathrm{SO}_{2}+\mathrm{NO}$ can increase the percentage for $\mathrm{Fe}_{0.8} \mathrm{Co}_{0.2} \mathrm{Ce}_{0.05} / \mathrm{ASC}$ and $\mathrm{Fe}_{0.8} \mathrm{Co}_{0.2} \mathrm{Ce}_{0.1} / \mathrm{ASC}$. We speculate that the increase is attributable to the generation of $\mathrm{Ce}_{2}\left(\mathrm{SO}_{4}\right)_{3}$. Notably, for $\mathrm{Fe}_{0.8} \mathrm{Co}_{0.2} \mathrm{Ce}_{0.1} / \mathrm{ASC}$, the influences of $\mathrm{SO}_{2}$ or $\mathrm{SO}_{2}+\mathrm{NO}$ are relatively analogous. Therefore, it is established that the sample $\mathrm{Fe}_{0.8} \mathrm{Co}_{0.2} \mathrm{Ce}_{0.1} / \mathrm{ASC}$ can obtain stable CO-deNO activity in the presence of $\mathrm{SO}_{2}$. With regard to the sample $\mathrm{Fe}_{0.8} \mathrm{Co}_{0.2} \mathrm{Ce}_{0.2} / \mathrm{ASC}$, the $\mathrm{Ce}^{3+}$ proportion is relatively low all through the different conditions. This may be due to the larger amount of $\mathrm{Ce}^{4+}$ ions produced by a larger amount of cerium oxides loaded.
The $\mathrm{S} 2 \mathrm{p}$ curves are displayed in Fig. 9. As shown in this figure, it can be observed that except for $\mathrm{Fe}_{0.8} \mathrm{Co}_{0.2} \mathrm{Ce}_{0.1} / \mathrm{ASC}$, the other three samples exhibit variations in the percentages of $\mathrm{SO}_{4}{ }^{2-}$ under different treatments (i.e., the introduction of NO can increase the $\mathrm{SO}_{4}{ }^{2-}$ proportion obviously). For $\mathrm{Fe}_{0.8} \mathrm{Co}_{0.2^{-}}$ $\mathrm{Ce}_{0.1} / \mathrm{ASC}$, the $\mathrm{SO}_{2}$-pretreated sample's percentage is $51.80 \%$, while that of the $\mathrm{SO}_{2}+$ NO-pretreated sample is $52.08 \%$. This slight variation corresponds to the analysis of the $\mathrm{Ce}^{3+}$ ion. This is reasonable to demonstrate that when the doping ratio of Ce is approximately 0.1 , the excellent $\mathrm{SO}_{2}$ tolerance is ascribable to the generation of $\mathrm{Ce}_{2}\left(\mathrm{SO}_{4}\right)_{3}$ accumulating in the surrounding cerium oxide lattice.

\subsection{DRIFTS analysis}

To investigate the interaction of surface sulfates with NO or the surface metal ion, in situ DRIFTS was performed. First, we investigated the interaction of $\mathrm{SO}_{2}$ and the catalyst surface. Fig. 10 shows the DRISTS spectra of the catalysts as a function of exposure time in a flow of $200 \mathrm{ppm} \mathrm{SO} \mathrm{S}_{2}$ at $250{ }^{\circ} \mathrm{C}$. As shown in Fig. 10(a), after $1 \mathrm{~min}$ of $\mathrm{SO}_{2}$ exposure, there are several bands appearing at $1084 \mathrm{~cm}^{-1}, 1140 \mathrm{~cm}^{-1}, 1389 \mathrm{~cm}^{-1}, 1535 \mathrm{~cm}^{-1}$, $1638 \mathrm{~cm}^{-1}$, and $1709 \mathrm{~cm}^{-1}$ for $\mathrm{Fe}_{0.8} \mathrm{Co}_{0.2} / \mathrm{ASC}$. The bands at $1084 \mathrm{~cm}^{-1}, 1140 \mathrm{~cm}^{-1}$ and $1389 \mathrm{~cm}^{-1}$, are assigned to $\nu_{\mathrm{s}}\left(\mathrm{SO}_{4}{ }^{2-}\right)$, 

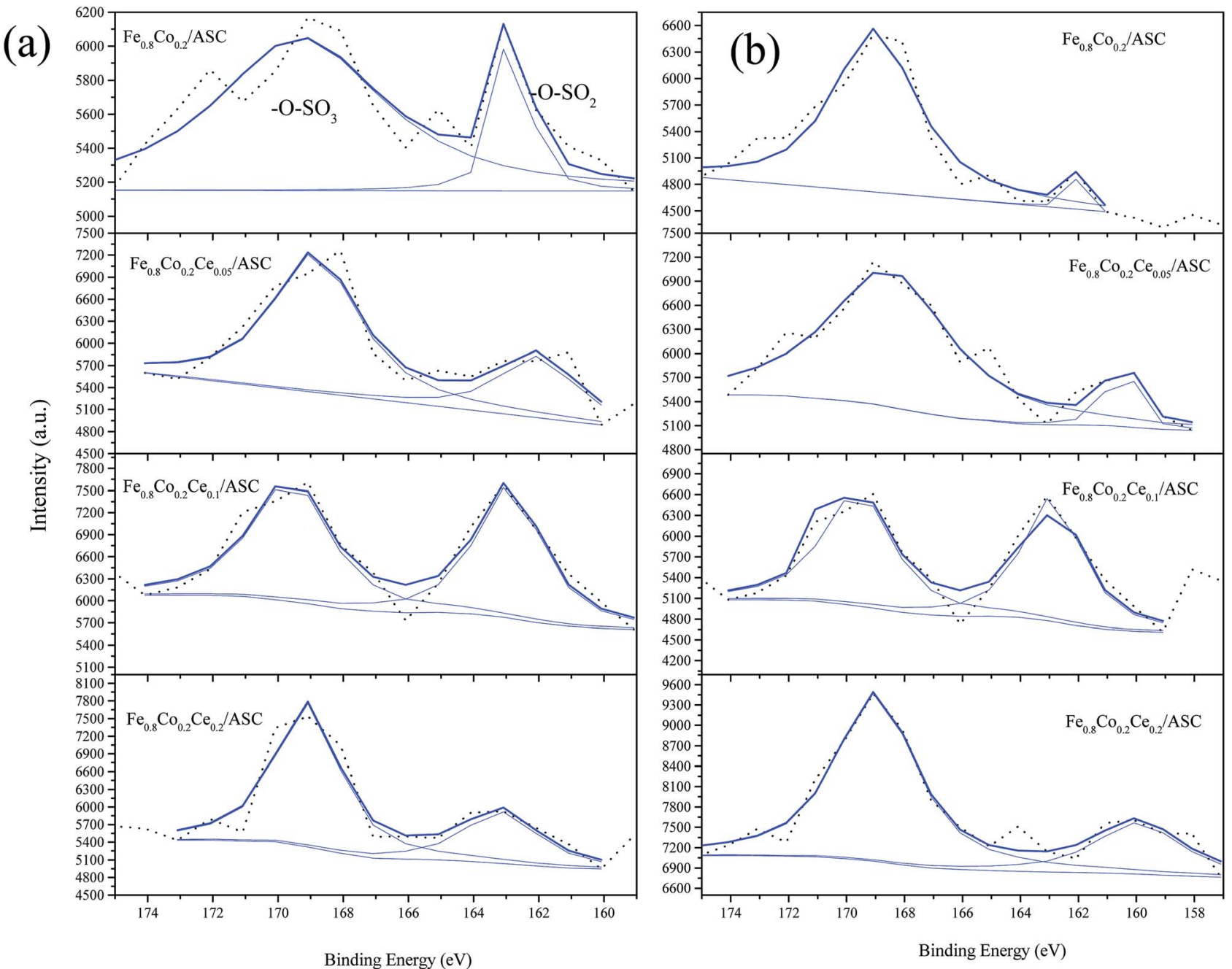

Fig. $9 \mathrm{~S} 2 \mathrm{p}$ from XPS spectra of catalysts with different treatment: (a) $200 \mathrm{ppm} \mathrm{SO} \mathrm{S}_{2}$ pretreated at $250{ }^{\circ} \mathrm{C}$; (b) $200 \mathrm{ppm} \mathrm{SO}+1000 \mathrm{ppm} \mathrm{NO}$ pretreated at $250{ }^{\circ} \mathrm{C}$.

$\nu_{\text {as }}(\mathrm{S}=\mathrm{O})$ of bidentate sulfites, and $\nu(\mathrm{S}=\mathrm{O})$ of surface sulfates with only one $\mathrm{S}=\mathrm{O}$ bond, ${ }^{5,33,36}$ respectively. While, the bands in the wavenumber range of $1500-1750 \mathrm{~cm}^{-1}$ should be assigned to $\nu\left(\mathrm{SO}_{4}{ }^{2-}\right)$ coordinated with $\mathrm{Fe}^{3+}$ or $\mathrm{Co}^{x+} \cdot{ }^{33,36}$ Moreover, the bands at $1084 \mathrm{~cm}^{-1}, 1140 \mathrm{~cm}^{-1}$ and $1389 \mathrm{~cm}^{-1}$ grow in intensity with exposure time until they become stable; whereas, the
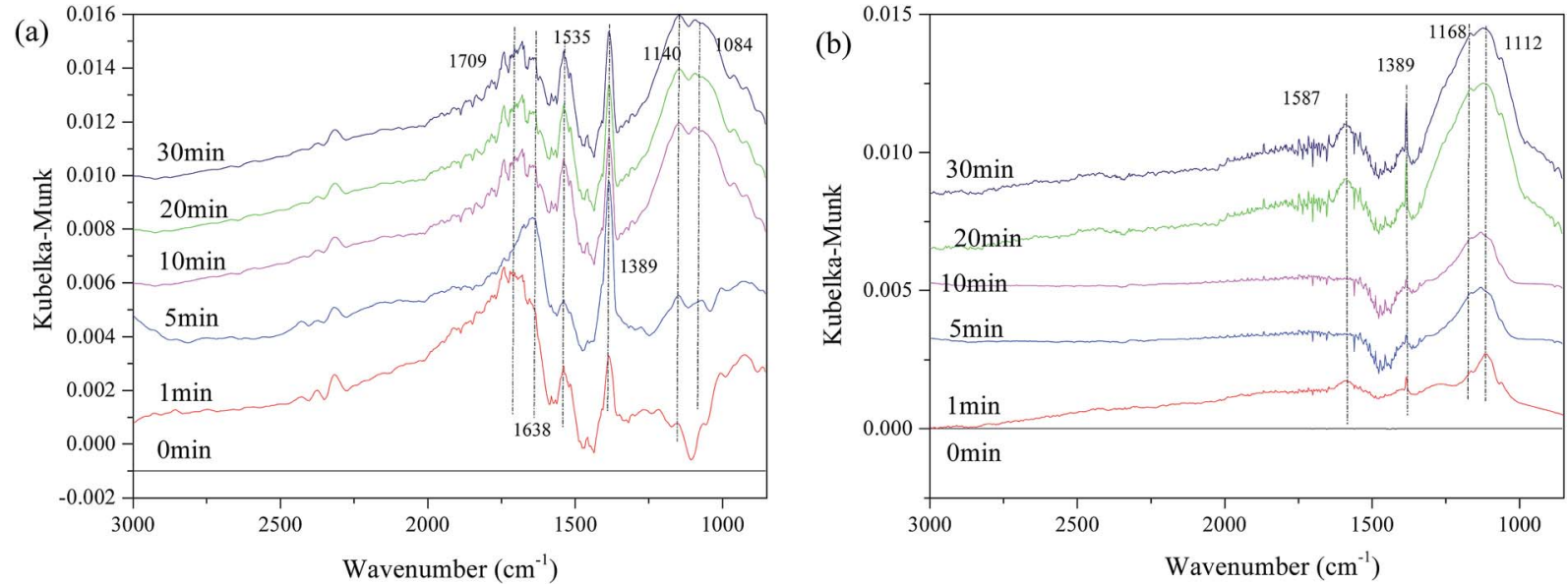

Fig. 10 DRIFTS spectra of catalysts: (a) $\mathrm{Fe}_{0.8} \mathrm{Co}_{0.2} / \mathrm{ASC}$; (b) $\mathrm{Fe}_{0.8} \mathrm{Co}_{0.2} \mathrm{Ce}_{0.1} / \mathrm{ASC}$; exposed to 200 ppm $\mathrm{SO}_{2}$ balanced by $\mathrm{N}_{2}$ at $250{ }^{\circ} \mathrm{C}$ for different times. 

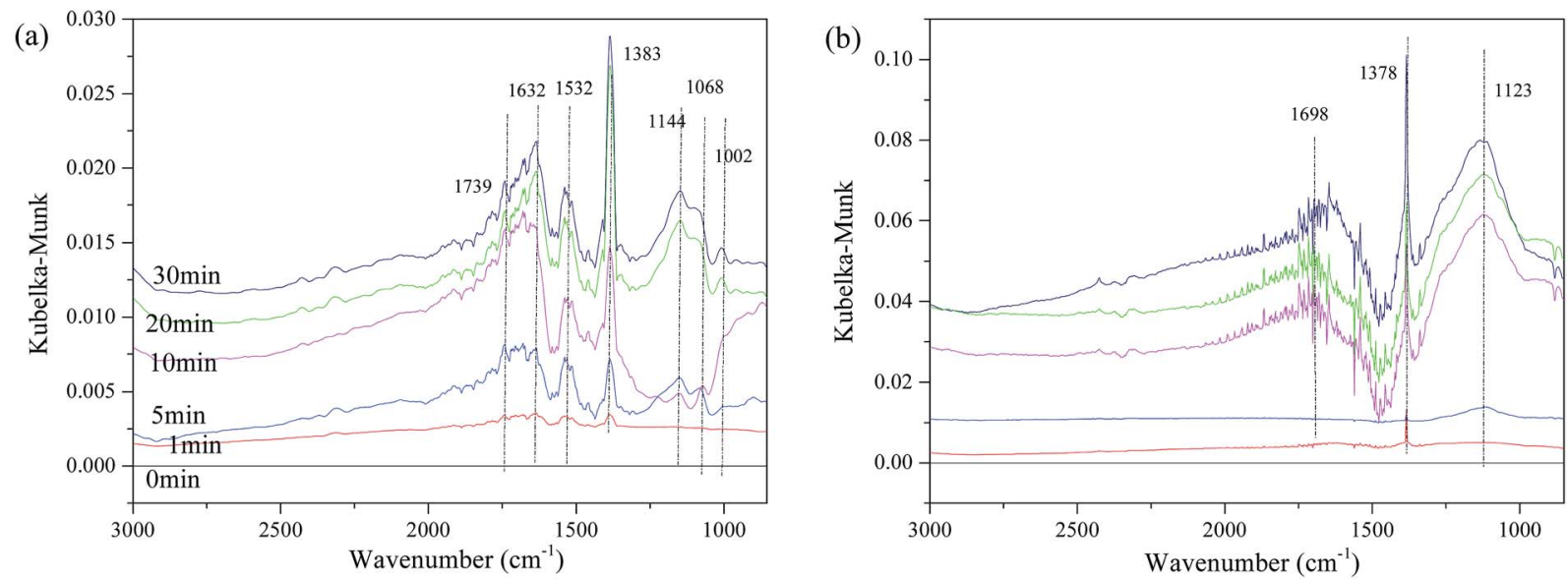

Fig. 11 DRIFTS spectra of catalysts: (a) $\mathrm{Fe}_{0.8} \mathrm{Co}_{0.2} / \mathrm{ASC}$; (b) $\mathrm{Fe}_{0.8} \mathrm{Co}_{0.2} \mathrm{Ce}_{0.1} / \mathrm{ASC}$; exposed to 200 ppm SO${ }_{2}+1000$ ppm NO balanced by N $\mathrm{N}_{2}$ at $250{ }^{\circ} \mathrm{C}$ for different times.

bands at $1535 \mathrm{~cm}^{-1}, 1638 \mathrm{~cm}^{-1}$ and $1709 \mathrm{~cm}^{-1}$ vary inconsistently. The intensity of the band at $1535 \mathrm{~cm}^{-1}$ first decreases and then increases with time, while the positions of the other bands shift until the broad, strong peak appears at approximate $1680 \mathrm{~cm}^{-1}$. It is speculated that during this variation, the surface sulfates evolve with the reaction time, in order to keep a steady state. Contrasting with the results in Fig. 10 (a), $\mathrm{Fe}_{0.8^{-}}$ $\mathrm{Co}_{0.2} \mathrm{Ce}_{0.1} / \mathrm{ASC}$ shows fewer bands (Fig. 10(b)): only four obvious bands at $1112 \mathrm{~cm}^{-1}, 1168 \mathrm{~cm}^{-1}, 1389 \mathrm{~cm}^{-1}$ and $1587 \mathrm{~cm}^{-1}$. These bands will grow in intensity with time, but will not change positions. Therefore, we speculate that the sulfates on the surface of $\mathrm{Fe}_{0.8} \mathrm{Co}_{0.2} \mathrm{Ce}_{0.1} / \mathrm{ASC}$ are more purified (i.e., the major sulfates are cerous sulfates).

The influence of NO on the surface sulfates was also investigated, and Fig. 11 displays the spectra of the representative samples. It can be observed in Fig. 11(a), that there are some bands assigned to $\nu$ of weakly adsorbed $\mathrm{NO}\left(1739 \mathrm{~cm}^{-1}\right)$, $\nu_{\text {as }}\left(\mathrm{NO}_{3}{ }^{-}\right)$in bridge bidentate coordination $\left(1632 \mathrm{~cm}^{-1}\right), \nu_{\text {as }}$ of nitro species $\left.\left(1383 \mathrm{~cm}^{-1}\right)\right)^{\mathbf{8}, 15,18,51}$ and $\nu$ of $\mathrm{SO}_{4}{ }^{2-}\left(1532 \mathrm{~cm}^{-1}\right.$, $1114 \mathrm{~cm}^{-1}, 1068 \mathrm{~cm}^{-1}$ and $1002 \mathrm{~cm}^{-1}$ ). The intensity of these bands increases with time, indicating that the reaction gradually reaches a steady state. The bands of $\nu_{\text {as }}$ (nitro species) should theoretically be located at approximately $1375 \mathrm{~cm}^{-1}$. This shifting is speculated to be related to the interaction of surface sulfates and $\mathrm{NO}_{2}{ }^{-}$. However, for $\mathrm{Fe}_{0.8} \mathrm{Co}_{0.2} \mathrm{Ce}_{0.1} / \mathrm{ASC}$, the

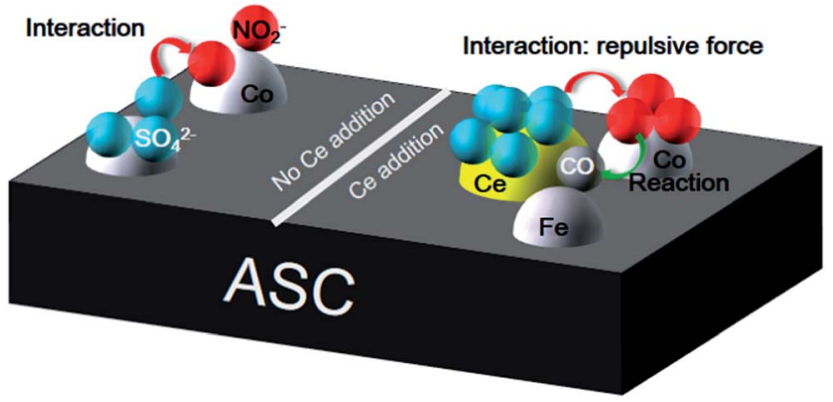

Fig. 12 A possible $\mathrm{SO}_{2}$ tolerance mechanism. band of $\nu_{\text {as }}$ (nitro species) has almost no shifting. In addition to the band at $1378 \mathrm{~cm}^{-1}$, bands also appear at $1698 \mathrm{~cm}^{-1}$ and $1123 \mathrm{~cm}^{-1}$. The intensity and half peak width simultaneously increase with the adsorbing time, indicating some bulk-like sulfates may be produced.

In conclusion, it can be deduced that with no Ce doping, there will be more kinds of sulfates like $\mathrm{Fe}_{2}\left(\mathrm{SO}_{4}\right)_{3}$ generated on the surface of $\mathrm{Fe}_{0.8} \mathrm{Co}_{0.2} / \mathrm{ASC}$. However, the addition of Ce can attract these sulfates and transform them to cerous sulfates. Nitro acts as an important intermediate in the $\mathrm{NO}+\mathrm{CO}$ reaction, ${ }^{27}$ but the presence of $\mathrm{SO}_{2}$ will affect the locating site of nitro species on the micro surface for Fe-Co binary catalysts. That will reduce the deNO activity. Meanwhile, the Ce addition can decrease the NO adsorption performance of the ASC-based catalysts in the presence of $\mathrm{SO}_{2}$, to some extent (this is also reasonable for the decrease of the NO conversion). Notably, cerium oxides show excellent performance for improving the generation of bulk-like cerous sulfates, which could remedy the decrease of CO-deNO activity, and further strengthen the $\mathrm{SO}_{2}$ resistance.

\section{7 $\mathrm{SO}_{2}$ tolerance mechanism}

After the analysis above, a possible scheme for the $\mathrm{SO}_{2}$ resistance mechanism in the NO + CO reaction over ASC-based catalysts is proposed. As shown in Fig. 12, when the catalyst surface has no Ce, the adsorbed $\mathrm{SO}_{2}$ will transform the active components to sulfate, and further deactivate the catalysts. Moreover, the $\mathrm{SO}_{2}$ presence could also change the form of the intermediates of nitrates. However, Ce doping can improve the $\mathrm{SO}_{2}$ tolerance in two aspects: one is protecting the active metal oxides; the other is stabilizing the form of the surface nitrates.

\section{Conclusions}

After a series of tests on the samples, the improvement in the $\mathrm{SO}_{2}$ tolerance for $\mathrm{Fe}_{0.8} \mathrm{Co}_{0.2} \mathrm{Ce}_{0.1} / \mathrm{ASC}$ in the $\mathrm{NO}+\mathrm{CO}$ reaction was revealed. The conclusions are as follows:

(1) The presence of $\mathrm{SO}_{2}$ in the feed gas can severely decrease the $\mathrm{CO}-\mathrm{deNO}$ activity catalyzed by $\mathrm{Fe}-\mathrm{Co}$ binary oxides over 
activated semi-coke. The doping of Ce onto the Fe-Co binary catalysts will improve the $\mathrm{SO}_{2}$ tolerance, and the optimizing doping molar ratio is approximately 0.1 .

(2) The Ce on the surface of catalysts can improve the generation of $\mathrm{Ce}_{2}\left(\mathrm{SO}_{4}\right)_{3}$. These sulfates will directly accumulate on the $\mathrm{Ce}^{x+}$ site, affording some bulk-like sulfates, which can then protect the active metal from poisoning by $\mathrm{SO}_{2}$.

(3) Although the addition of Ce will decrease the NOadsorption performance of the $\mathrm{Fe}-\mathrm{Co}$ binary catalysts, the presence of Ce plays an important role in protecting the formation of surface nitrates. Furthermore, this protection can alleviate the interaction of surface sulfates and nitrates.

\section{Conflicts of interest}

There are no conflicts to declare.

\section{Acknowledgements}

The authors thank the National Natural Science Foundation of China (No. 51406104), the National Key Technology R\&D Program (No. 2014BAA02B03), the National key R\&D program (No. 2017YFB0602904), the Project of Shandong Province Science and Technology Development Program (No. 2014GSF117034), Shandong Province Natural Science Foundation (No. ZR2016EEM17), and the Independent Innovation Funds of Shandong Province (No. 2014ZZCX05201) for financial support.

\section{References}

1 R. Jin, Y. Liu, Y. Wang, W. Cen, Z. Wu, H. Wang and X. Weng, Appl. Catal., B, 2014, 148-149, 582-588.

2 C. J. Tang, H. L. Zhang and L. Dong, Catal. Sci. Technol., 2016, 6, 1248-1264.

3 A. Boubnov, H. W. P. Carvalho, D. E. Doronkin, T. Gunter, E. Gallo, A. J. Atkins, C. R. Jacob and J. D. Grunwaldt, J. Am. Chem. Soc., 2014, 136, 13006-13015.

4 Y. Chen, J. Wang, Z. Yan, L. Liu, Z. Zhang and X. Wang, Catal. Sci. Technol., 2015, 5, 2251-2259.

5 L. Wang, X. Cheng, Z. Wang, C. Ma and Y. Qin, Appl. Catal., $B, 2017,201,636-651$.

6 R. Mrad, A. Aissat, R. Cousin, D. Courcot and S. Siffert, Appl. Catal., A, 2015, 504, 542-548.

7 G. H. Wang, R. Y. Zhang, M. E. Gomez, L. X. Yang, M. L. Zamora, M. Hu, Y. Lin, J. F. Peng, S. Guo, J. J. Meng, J. J. Li, C. L. Cheng, T. F. Hu, Y. Q. Ren, Y. S. Wang, J. Gao, J. J. Cao, Z. S. An, W. J. Zhou, G. H. Li, J. Y. Wang, P. F. Tian, W. Marrero-Ortiz, J. Secrest, Z. F. Du, J. Zheng, D. J. Shang, L. M. Zeng, M. Shao, W. G. Wang, Y. Huang, Y. Wang, Y. J. Zhu, Y. X. Li, J. X. Hu, B. Pan, L. Cai, Y. T. Cheng, Y. M. Ji, F. Zhang, D. Rosenfeld, P. S. Liss, R. A. Duce, C. E. Kolb and M. J. Molina, Proc. Natl. Acad. Sci. U. S. A., 2016, 113, 13630-13635.

8 X. Yao, Y. Xiong, W. Zou, L. Zhang, S. Wu, X. Dong, F. Gao, Y. Deng, C. Tang, Z. Chen, L. Dong and Y. Chen, Appl. Catal., B, 2014, 144, 152-165.
9 X. X. Cheng, M. Zhang, P. L. Sun, L. Y. Wang, Z. Q. Wang and C. Y. Ma, Green Chem., 2016, 18, 5305-5324.

10 X. X. Cheng and X. T. T. Bi, Int. J. Chem. React. Eng., 2013, 11, 19-30.

11 X. X. Cheng and X. T. T. Bi, Chem. Eng. J., 2012, 211, 453-462.

12 T. T. Yang, H. T. Bi and X. X. Cheng, Appl. Catal., B, 2011, 102, 163-171.

13 L. Dong, B. Zhang, C. Tang, B. Li, L. Zhou, F. Gong, B. Sun, F. Gao, L. Dong and Y. Chen, Catal. Sci. Technol., 2014, 4, 482-493.

14 C. Sun, Y. Tang, F. Gao, J. Sun, K. Ma, C. Tang and L. Dong, Phys. Chem. Chem. Phys., 2015, 17, 15996-16006.

15 Y. Xiong, X. Yao, C. Tang, L. Zhang, Y. Cao, Y. Deng, F. Gao and L. Dong, Catal. Sci. Technol., 2014, 4, 4416-4425.

16 Y. Xiaojiang, Y. Xiong, S. Jingfang, G. Fei, D. Yu, T. Changjin and D. Lin, J. Rare Earths, 2014, 32, 131-138.

17 C. Ge, L. Liu, Z. Liu, X. Yao, Y. Cao, C. Tang, F. Gao and L. Dong, Catal. Commun., 2014, 51, 95-99.

18 Y. Lv, L. Liu, H. Zhang, X. Yao, F. Gao, K. Yao, L. Dong and Y. Chen, J. Colloid Interface Sci., 2013, 390, 158-169.

19 L. Qi, Q. Yu, Y. Dai, C. Tang, L. Liu, H. Zhang, F. Gao, L. Dong and Y. Chen, Appl. Catal., B, 2012, 119-120, 308-320.

20 L. Liu, Y. Chen, L. Dong, J. Zhu, H. Wan, B. Liu, B. Zhao, H. Zhu, K. Sun, L. Dong and Y. Chen, Appl. Catal., B, 2009, 90, 105-114.

21 L. Simonot and G. Maire, Appl. Catal., B, 1997, 11, 181-191. 22 L. Zhang, L. Dong, W. Yu, L. Liu, Y. Deng, B. Liu, H. Wan, F. Gao, K. Sun and L. Dong, J. Colloid Interface Sci., 2011, 355, 464-471.

23 C. Tang, B. Sun, J. Sun, X. Hong, Y. Deng, F. Gao and L. Dong, Catal. Today, 2017, 281, 575-582.

24 D. Li, Q. Yu, S.-S. Li, H.-Q. Wan, L.-J. Liu, L. Qi, B. Liu, F. Gao, L. Dong and Y. Chen, Chem.-Eur. J., 2011, 17, 5668-5679.

25 X. Yao, C. Tang, Z. Ji, Y. Dai, Y. Cao, F. Gao, L. Dong and Y. Chen, Catal. Sci. Technol., 2013, 3, 688-698.

26 C. Sun, J. Zhu, Y. Lv, L. Qi, B. Liu, F. Gao, K. Sun, L. Dong and Y. Chen, Appl. Catal., B, 2011, 103, 206-220.

27 L. Wang, Z. Wang, X. Cheng, M. Zhang, Y. Qin and C. Ma, RSC Adv., 2017, 7, 7695-7710.

28 L. Wang, X. Cheng, Z. Wang, X. Zhang and C. Ma, Can. J. Chem. Eng., 2017, 95, 449-458.

29 Y. Yu, J. Wang, J. Chen, X. Meng, Y. Chen and C. He, Ind. Eng. Chem. Res., 2014, 53, 16229-16234.

30 W. S. Kijlstra, M. Biervliet, E. K. Poels and A. Bliek, Appl. Catal., B, 1998, 16, 327-337.

31 T. Shaymurat, Q. Tang, Y. Tong, L. Dong and Y. Liu, Adv. Mater., 2013, 25, 2269-2273.

32 A. Venezia, G. Di Carlo, L. Liotta, G. Pantaleo and M. Kantcheva, Appl. Catal., B, 2011, 106, 529-539.

33 W. Q. Xu, H. He and Y. B. Yu, J. Phys. Chem. C, 2009, 113, 4426-4432.

34 S. T. Choo, S. D. Yim, I.-S. Nam, S.-W. Ham and J.-B. Lee, Appl. Catal., B, 2003, 44, 237-252.

35 T. Kanazawa, Catal. Today, 2004, 96, 171-177.

36 B. Jiang, B. Deng, Z. Zhang, Z. Wu, X. Tang, S. Yao and H. Lu, J. Phys. Chem. C, 2014, 118, 14866-14875. 
37 H. Chang, X. Chen, J. Li, L. Ma, C. Wang, C. Liu, J. W. Schwank and J. Hao, Environ. Sci. Technol., 2013, 47, 5294-5301.

38 K. Wijayanti, K. Leistner, S. Chand, A. Kumar, K. Kamasamudram, N. W. Currier, A. Yezerets and L. Olsson, Catal. Sci. Technol., 2016, 6, 2565-2579.

39 L. Xie, F. Liu, L. Ren, X. Shi, F.-S. Xiao and H. He, Environ. Sci. Technol., 2013, 48, 566-572.

40 L. Xie, F. Liu, K. Liu, X. Shi and H. He, Catal. Sci. Technol., 2014, 4, 1104-1110.

41 Q. Yang, H. Choi, S. R. Al-Abed and D. D. Dionysiou, Appl. Catal., B, 2009, 88, 462-469.

42 K. Asami and K. Hashimoto, Corros. Sci., 1984, 24, 83-97.

43 G. A. Kolta and M. H. Askar, Thermochim. Acta, 1975, 11, 6572.

44 G. Xie, Z. Liu, Z. Zhu, Q. Liu, J. Ge and Z. Huang, J. Catal., 2004, 224, 42-49.
45 T. Luo, J. M. Vohs and R. J. Gorte, J. Catal., 2002, 210, 397404.

46 M. C. Biesinger, B. P. Payne, A. P. Grosvenor, L. W. M. Lau, A. R. Gerson and R. S. C. Smart, Appl. Surf. Sci., 2011, 257, 2717-2730.

47 T. Yamashita and P. Hayes, Appl. Surf. Sci., 2008, 254, 24412449.

48 A. P. Grosvenor, B. A. Kobe, M. C. Biesinger and N. S. McIntyre, Surf. Interface Anal., 2004, 36, 1564-1574.

49 A. S. Arico, A. K. Shukla, H. Kim, S. Park, M. Min and V. Antonucci, Appl. Surf. Sci., 2001, 172, 33-40.

50 A. Kocijan, I. Milošev and B. Pihlar, J. Mater. Sci.: Mater. Med., 2004, 15, 643-650.

51 M. C. Kung and H. H. Kung, Catal. Rev.: Sci. Eng., 1985, 27, 425-460. 